\title{
Torn Asunder from Within: Ukraine and the Lessons for Global Security
}

\section{Iryna Klymenko}

\author{
"New Ukraine" Institute of Strategic Studies, Kyiv, Ukraine
}

\begin{abstract}
Russia's non-standard intervention in Ukraine was accomplished in four major areas - the economic system as a whole, the energy and security sectors, and information policy. The deliberate policy of the Kremlin has transformed Ukraine into economically fragile and institutionally weak nation. Due to efforts of former regime and Russian intelligence agencies, main Ukrainian government institutions were involved in semi-legal, semi-criminal transnational business scheme. Macro-financial vulnerability of Ukraine, in conjunction with a strained economic structure, proved to be the necessary and sufficient conditions for preparing and implementing hybrid aggression. The Ukrainian precedent might be replicated as a special operation to destroy statehood, whereby disruption is achieved through the escalation of internal political and economic challenges. One universal means of undermining statehood in an era of hybrid wars is to encourage corruption among holders of the highest office.
\end{abstract}

Keywords: intervention, security policy, hybrid war, informational warfare, systemic corruption, illegal economy, criminal business.

\section{Introduction}

Ukraine is undergoing a very difficult period in its history. The country is bidding farewell to its Soviet past, while the Russian Federation (RF) is attempting to restore the "Soviet Empire" - with Ukraine retaining within its sphere of control. The Ukraine drama has been playing out "online" before our very eyes, and events have developed so rapidly that experts and scholars are not only unable to keep up with all the details, but are experiencing great difficulty making sense of what is happening. 
A brief chronology of the crisis that ushered in the "strange" Russia-Ukraine is as follows. Late in the day on 21 November 2013, young Ukrainians gathered in peaceful protest of the government's decision to suspend the process of Ukraine's integration into the European Union; about 2,000 people took to Kyiv's Maidan square. However, a violent dispersal of the tent city followed in the early hours of 30 November, after the failure of the Eastern Partnership Summit in Vilnius on 28-29 October. On 1 December a crowd of citizens, variously estimated at 400,000 to 800,000 , gathered at Maidan. ${ }^{1}$ This action assumed a distinctly anti-presidential and anti-government tone. Tensions between the protestors and security forces rose quickly and led to numerous clashes between them. The Ukrainian leadership tried in vain to stop the protests. On 16 January, despite blatant violations of procedural rules, the Ukrainian parliament approved anti-protest laws that greatly restricted the protestors' constitutional rights. On 19 January 2014 the confrontation escalated dramatically, with skirmishes between radical demonstrators and police. During the period of 21-22 January, three people died of gunshot wounds and many protestors were injured. By 18 February, yet another escalation of the situation led to mass bloodshed. According to the Ukrainian Ministry of Public Health, 77 people died in Kyiv from 18 to 21 February, with the Ministry of Internal Affairs reporting 16 police officers dead.

This day proved to be a turning point and within the next few days a shift in power occurred. On 23 February the Ukrainian parliament assigned the duties of the president of Ukraine to the chairman of the Verkhovna Rada (unicameral parliament), Oleksandr Turchynov. Over the period of 23-27 February, this was followed by a change in the executive bodies of Sevastopol and the Autonomous Republic of Crimea. The new authorities in Crimea refused to recognize the legitimacy of the new Ukrainian government and appealed to the leaders of the RF for its good offices and assistance. Then, in the course of the next few weeks, the new leadership of the Autonomous Republic of Crimea and Sevastopol unilaterally declared Crimea's independence and held a referendum. On 18 March an agreement was signed between the RF and the Republic of Crimea to accept the Republic of Crimea as part of Russia. After the annexation of Crimea, the focal point of tension shifted to the southeast of Ukraine. In other words, the members of local government bodies in some eastern regions followed Crimea's example of refusing to recognize Kyiv's authority and adopted resolutions stating their readiness to assume responsibility for defending constitutional order within their territories. Further, they declared that recent events in Kyiv had led to the paralysis of central authority and destabilization of the country.

On 7 April 2014 Ukraine's acting president Oleksandr Turchynov declared the start of an "anti-terrorist operation." On 12 April the terrorists seized the

1 “1 December 2013 Euromaidan riots," Wikipedia: The Free Encyclopedia, available at http://en.wikipedia.org/wiki/1_December_2013_Euromaidan_riots (accessed 5 August 2014). 
first city - Slavyansk. The immediate consequences of this acute phase of the social and political crisis indicate that Ukraine had become the object of a new sort of aggression encompassing the following:

- the annexation of the Autonomous Republic of Crimea (occupation and illegal inclusion into the RF);

- destabilization of the western and eastern regions of Ukraine and incitement to separatism (armed conflicts involving special forces and military mercenaries of a foreign origin, primarily from the RF; the declaration of new states; and attempts to illegally change Ukraine's constitutional order);

- the RF's unilateral disregard for and de facto failure to comply with the entire range of bilateral regulatory agreements and treaties forming the basis of Ukrainian-Russian relations (primarily the Treaty on Friendship, Cooperation and Partnership between Ukraine and the RF);

- the waging of an information war against Ukraine, unprecedented in scale of with regard to falsifications and insinuations;

- the discrediting of existing international treaties designed to guarantee the security and integrity of the Ukrainian state (borders, non-interference in domestic affairs, economic security, etc.);

- a de facto annulment of the 1994 Budapest Memorandum on Security Assurances, under which nuclear states guarantee Ukraine's security; a shattering of the regime of non-proliferation. ${ }^{2}$

At the same time, there are grounds to believe that the RF was secretly preparing to undermine Ukrainian statehood. As early as 2008, Ukrainian special services were informed of plans in the RF to invade the Crimean Peninsula, as evidenced by data on reconnaissance missions that had been initiated. ${ }^{3}$ Parallel to this, at the 2008 NATO-Russia Summit in Bucharest, President Vladimir Putin of the RF declared that Ukraine was an artificial state with seventeen million Russians living in it. A month later, the RF incorporated changes into its national legislation, granting it the right to "defend" Russian populations beyond the borders of the state. Accordingly, credence can be given to some experts' claims that in 2008 the RF initiated a new type of undeclared aggression against Ukraine, using techniques that provided an "impetus toward" and/or "an awakening" of internal molecular conflicts (that is, non-conventional or hybrid

2 More details in: "Memorandum. Lessons from the Ukraine Crisis: New Approaches to Security Policy (global, regional, national)" ("New Ukraine" Institute of Strategic Studies, 5 June 2014), available at http://newukraineinstitute.org/new/399 (accessed 26 July 2014).

3 Ivan Kapsamun, "Regarding the Watershed Line," Interview with Valentin Nalivaychenko, Den [The Day], 19 June 2014, available at http://www.day.kiev.ua/ru/ article/podrobnosti-intervyu/o-linii-vodorazdela. 
warfare, non-standard armed conflict, etc.). ${ }^{4}$ Consequently, in the spring of 2014 this war moved from a latent to an open phase.

\section{The Transformation of Ukraine under the Aggressor's Pressure}

Back in 2008, Putin's declaration seemed more like a wishful objective. Five years later, in 2013, the Ukraine of Yanukovych-Putin was dangerously close to the line beyond which Ukrainian statehood would de facto-and then perhaps de jure-cease to exist. Concerted actions by Russian officials resulted in the so-called "Yanukovych vertical" being firmly woven into a system of making Russia's interests a reality. The RF's non-standard intervention in Ukraine (prior to 2014) was accomplished in four major areas - the economic system as a whole, the energy and security sectors, and information policy.

The Russian president was well-informed about the specifics of ex-president Yanukovych's corporate state. This gave him the confidence to posit that Ukraine was "not a state" in the usual sense of the term and, based on that understanding, to determine the permissible level of interference in Ukraine's domestic and foreign policy. If personal enrichment was the highest objective for Yanukovych in all spheres of the country's life, for the Putin regime the range of tasks was significantly wider. In the economic realm, the RF's objective was to tie Ukraine tightly to Russia without allowing any alignment with the European Union or the US, and to impede the institutional and structural modernization of the economy. ${ }^{5}$ Increasing Ukraine's energy dependence did not so much make it easier to accomplish those goals as it expanded the opportunities for the Kremlin to pursue a policy of energy overlording at the international level. ${ }^{6}$ Ultimately, the transformation of government institutions into a centralized system and withdrawing resources from the economy created broad opportunities for the RF to "make wholesale purchases of the country's political and military leadership" and to "clone" within Ukraine a quasi-state modeled after Russia. $^{7}$

4 One of the most consistent proponents of this approach is A. Illarionov, Senior Fellow at the Cato Institute, former advisor to the president of Russia, and former director of the Institute for Economic Analysis. For instance, in his statement to the Foreign Affairs Committee of the U.S. House of Representatives during the 2009 hearings, "From Competition to Collaboration: Strengthening the U.S.-Russia Relationship," he presented a list of nine "non-conventional" wars initiated by the Russian Federation. Available at http://www.cato.org/publications/congressional-testimony/ competition-collaboration-strengthening-usrussia-relationship. Iryna Klymenko, et al., The Prospects for Relations between Ukraine and the Customs Union of the Republic of Belarus, the Republic of Kazakhstan and the Russian Federation (Kyiv: National Institute for Strategic Studies, 2011), 59 (in Russian).

6 Iryna Klymenko, et al., Ukraine in Integration Processes in the Post-Soviet Space: Modeling Alternatives. (Kyiv: National Institute of Strategic Studies, 2013), 44 (in Russian).

7 Address by Andrey Illarionov, Senior Fellow at the Center for Global Liberty and Prosperity, Cato Institute, Washington, D.C., at a meeting of the Economic and Security Committee of the NATO Parliamentary Assembly, Vilnius, 31 May 2014, available at 
Informational interventions pursuing the dual purpose of aggression and deception utilized numerous methods of informational and psychological warfare ranging from the posting of tendentious information and half-truths to outright lies (hoaxes). Intended to support the communication and organizational implementation of the RF's predatory objectives in Ukraine, these informational interventions produced a specific "picture of the world" for consumption by Russian and Ukrainian citizens. For example, the vast propaganda campaign that accompanied the preparation and conduct of special operations to annex Crimea was dispersed over several areas. ${ }^{8}$ This included several key objectives: (1) to demoralize the Ukrainian population; (2) to demoralize the armed forces and security agencies and to induce them to commit high treason; (3) to create a distorted "media picture" of events in the minds of Russian and Ukrainian citizens; (4) to create the illusion of mass support for the actions of the RF among the population of the southeastern regions of Ukraine; (5) to lend psychological support to adherents of radical alignment of Ukraine's eastern and southern regions with Russia; (6) to entice Western media to report events with a pro-Russian slant.

Control over the Ukrainian security sector ensured the coordination of all the components of the Russian aggression in Ukraine during the latent aggression phase. Access to the operational management of the security sector allowed the RF to exercise day-to-day control of information flows in Ukraine including compromising information about the highest-level state officials. This prevented any political decisions objectionable to the RF and removed other threats to achieving the RF's objectives at the regional and global levels. According to testimony by Valentyn Nalyvaichenko, head of the Security Service of Ukraine (SSU), "...the 'legacy' of the Security Service of Ukraine after Yakymenko's leadership and in general during Yanukovych's tenure was a huge blow to the security of our country. The people who allowed it to happen-and who actually aided the enemy-are essentially state criminals." ${ }^{9}$

As can be surmised from the annexation of Crimea, the strategic goal of the RF's Special Services was to deprive Ukraine of the ability to defend itself in the event of open aggression, and this goal was achieved. It was at this juncture that the new leaders of the country discovered that the Ukrainian defense system was practically non-existent. Ukrainian experts who studied and reconstructed the motives behind various decisions on military security that predicated the Ukrainian army's loss of defensive capacity concluded that there was

http://www.youtube.com/watch?v=J8ISQpbfoBI (accessed 23 July 2014). The Russian version was is available at http://aillarionov.livejournal.com/696982.html (accessed 23 June 2014).

8 "Regarding the Informational and Psychological Component of the Russian Federation's Aggression against Ukraine," based on events of 1-2 March 2014 (Kyiv: Institute of Strategic Studies, 2014), available at http://en.niss.gov.ua/public/File/ englishpublic/Russia_aggression.pdf (accessed 23 June 2014) (in Russian).

9 Ivan Kapsamun, "Regarding the Watershed Line," Den [The Day], 19 June 2014 (in Russian). 
ongoing covert interference by the RF in matters related to the state's management of the defense sector on a tactical and strategic level. ${ }^{10}$ Staff appointments to executive military posts, management, financial, and especially political decisions on Ukrainian defense matters were constantly subject to intervention and adjustment from the RF. The last defense ministers of Ukraine (in Yanukovych's government), as noted in the study mentioned above, were citizens of the RF. ${ }^{11}$

Despite the widespread opinion that Putin could not fully depend on the fugitive Ukrainian president's loyalty, in Yanukovych he had a supporter, a likeminded person, and a follower, as the regimes the two of them were building in their respective countries were of the same type. There is no question that Yanukovych's Ukraine was complementary to Putin's Russia, although it did have certain important distinctions concerning practices of the criminal world.

\section{The Taking of Ukraine}

After Yanukovych fled and power changed hands in Ukraine, isolated data about the scale of the erosion of national identity have been gradually accumulated, analyzed, and summarized. However, many gaps remain in the overall picture. Important testimonies have either been irretrievably lost or intentionally concealed from the public. ${ }^{12}$ Ukraine's official bodies have not yet completed their investigations and have not managed to process all the information in their possession. Thus, the public discourse is dominated by perceptions based more on journalistic materials than on official sources. For example, an examination of objects and documents that could not be removed from Yanukovych's residence simply due to lack of time points to the man being pathologically obsessed with his own personal enrichment. ${ }^{13}$

The hierarchy of corruption was structured so as to ensure an uninterrupted flow of money and material resources, ranging from the collection of tributes from small shopkeepers, bribery, the sale of job positions, and the seizure of businesses to illegal sequestration of budgetary funds. In this system, every government institution, every element of state governance, was dedicated to generating income for the personal treasury of the ex-president and his entourage. Accordingly, defense and law enforcement agencies were used primarily to serve the personal economic interests of the regime members: (1) collection

10 For more details see: Regarding the decline (partial loss) of Ukraine's defense capabilities (2000-2014). Expert study (Kyiv: Center for Army, Conversion and Disarmament Research, Defense Express, 2014), available at http://issuu.com/ukrainian_

11

12

13 defense_review/docs/(in Russian).

Ibid., 76.

According to testimony by the head of the Security Service of Ukraine, beginning in December 2013 the ex-president's associates began to systematically destroy existing records of unprecedented thefts and other crimes by the regime.

"Yanukovych's assets: a public initiative to gather information about the illicit assets of ex-president Yanukovych and his associates," available at http://Yanukovych.info/ ru/viktor-yanukovych/ (in Russian). 
of information (economic, financial, compromising, and so forth) about potential victims; (2) coercion (blackmail or the use of force); (3) collection of payments (legal and illegal); and (4) providing security for the hierarchy and the system of control it had created.

In April 2014 the State Financial Monitoring Service announced the interim findings (for March) of an investigation into the laundering of funds received from corruption and from the embezzlement of government funds and property by the former President of Ukraine and his relatives, as well as by officials of the former government and their associates. According to these materials, the total sum of financial transactions suspected of being involved in legalizing illegally-obtained income stands at UAH 77.2 billion (about USD nine billion). Incidentally, this number is absent from the English-language version of the agency's website. $^{14}$

After coming to power in 2010, Yanukovych developed a strictly vertical hierarchy for managing the flow of money by eliminating competitors and simplifying the operational control of cash deliveries. ${ }^{15} \mathrm{It}$ is evident that the system for expropriating money from the Ukrainian economy was honed to the point that the amounts of riches accumulated over the years of Yanukovych's time in office could be comparable to the country's entire national budget. An analysis of the risks to the 2014 national budget, prepared during Yanukovych's tenure, makes it possible to measure the scale of the ex-president's ambitions during the last year he was in power (the next scheduled presidential elections were planned for early 2015). Experts estimated the possible losses to the budget resulting from schemes bearing the signs of corruption risks at about USD 24 billion (or nearly half of all budgetary expenditures). ${ }^{16}$

While preparing the present material, the author discovered a great number of testimonies and estimates in the independent media describing schemes for illegal expropriation of funds from the Ukrainian economy. In fact, the total amount of stolen resources-from USD 17-30 billion, according to various estimates-today serves to financially support the undeclared war in Donbass. Moreover, it is interesting to note that some elements of these schemes were put together long before Yanukovych's time. The tax machinations, along with smuggling and gas schemes, became the most profitable sectors of the shadow economy, commanding fierce competition for their control, not excluding the competition of winning the presidency and gaining a majority in parliament. It

14 "Information from the State Financial Monitoring Service" (9 April 2014). Accessed on 28 July 2014 at http://www.sdfm.gov.ua/news.php?news_id=2546\&lang=uk; http://www.sdfm.gov.ua/news.php?news_id=2592\&lang=en.

15 Some informed sources have indicated in personal conversations that Yanukovych preferred not to keep money in banks, but accumulated it in the form of cash, gold and precious material goods. This is indirectly confirmed by video footage of surveillance cameras in his residence that became available after he fled.

16 Ivan Sikora, "Budget-2014: Systemic Risks Costing over 188 Billion UAH" (Open Society Foundation, 14 January 2014), available at http://osf.org.ua/policy-analysisparlament/view/88. 
would be difficult to presume these schemes are gone along with ex-president Yanukovych. To assess the scale of the degradation of government institutions and to better understand the challenges faced by Ukraine's new leaders given the conflict in Eastern Ukraine, it is worthwhile looking at the sources of Yanukovych's accumulated riches.

Example 1. According to estimates by the Ministry of Revenues and Duties, losses from so-called "tax pits" (companies for exempting profits from taxation) for 2011-2013 totaled USD 37 billion (i.e., USD 12.5 billion per year). ${ }^{17}$ The scheme permeated the entire fiscal system of Ukraine and was controlled by the heads of the State Tax Administration, the State Customs Committee, and other regulatory bodies. Each of these government institutions was obliged to regularly transfer a fixed sum of cash to Yanukovych's associates.

Example 2. Public procurement is yet another thoroughly corrupt method of extracting resources from the economy. As a rule, only companies affiliated with the highest-ranking individuals in the regime could win formally competitive tenders to execute large government projects. ${ }^{18}$ In addition, the value of the projects put up for competitive bidding had to be overstated by at least a factor of two. The scale of misappropriation from the central budget alone, and in state procurement alone, was estimated at USD 10 billion. ${ }^{19}$

Example 3. Control of government assets and access to the management and financial resources of state companies made it possible on the one hand to manipulate the assets under their control, and on the other hand to steal lending resources made available under government guarantees. As of March 2014, the total indebtedness of state-owned companies was UAH 140 billion (about USD 13 billion). ${ }^{20}$ All these companies, like many other state-owned companies (for example, Energoatom, which produces electricity at nuclear stations), are unprofitable business entities, that is, they are incapable of functioning without support from the state budget. The Naftogaz company, a monopolistic operator in Ukraine's gas market, is an exception. The company's debt to creditors (USD 7.7 billion) came about largely as a result of machinations aimed at extracting funds from companies. According to various esti-

17 Minutes of a plenary session of the Supreme Rada of Ukraine (Parliament of Ukraine), 19 June 2014, available at http://iportal.rada.gov.ua/meeting/stenogr/ show/5641.html.

18 Unfortunately, this practice continues, with information appearing regularly on a website created by independent journalists for tracking corruption connections during government procurement actions; available at http://nashigroshi.org (in Russian).

Sergey Lyamets, "Vladimir Dubrovksy: the Top-Down Power Structure Must Be Destroyed," Ekonomichna Pravda [Economic Truth], 18 June 2014, available at http://www.epravda.com.ua/publications/2014/06/18/466239/ (in Russian).

20

"The sum total of state companies' debt is 140 billion UAH - Yatsenyuk," RBCUkraine, 27 March 2014, available at www.rbc.ua/rus/news/politics/obshchayasumma-dolgov-gosudarstvennyh-kompaniy-sostavlyaet-27032014104500/ (in Russian). 
mates, Yanukovych's associates made over USD 3 billion per year on these schemes. $^{21}$

Example 4. Only companies that either belonged to the ex-president's circle or shared some of the benefits with him (usually 30-50\%) enjoyed state support. In the coal industry alone, budgetary subsidies for coal extraction doubled-to USD 1.5 billion-during the period of 2009-2013. ${ }^{22}$ Illegal coal mining was a second element of the coal subsidies scheme. By early 2014 coal extraction in makeshift mines had reached a record mark of six million metric tons, or practically $10 \%$ of all the coal produced in the country. ${ }^{23}$ The direct gain from illegal activities is estimated at USD 250 million per year. ${ }^{24}$

If the proposition that the Russian and Ukrainian political and economic systems were operating in a complementary fashion during the period leading up to the Ukraine crisis in late 2013 is valid, it follows that Yanukovych's and Putin's main political objectives coincided. The former sought to strengthen a criminal and corrupt regime, the latter to maintain Ukraine as a non-democratic and non-free country within the RF's zone of control. Evidently, it was during the summer of 2013 that the Ukrainian ex-president made the final decision to break off relations with the West. This conclusion is based on the author's personal impressions and knowledge of the current problems of Ukraine's top leadership. In particular, apprehensions regarding future elections, the imminent economic crisis, and the RF's political blackmail were frequently expressed in meetings of the president's administration and of the government. Thus, underlying the ex-president's decision were the following motives: 1 ) the threat of losing sources of personal enrichment as a result of the coming financial and economic crisis; 2) the lack of prospects for quickly compensating for that income by integrating with the EU ${ }^{25}$ and the threat of the enrichment scheme falling apart as a result of implementing an association;

21 For example, the oil and gas company "Naftogaz" purchases 18 billion cubic meters of domestically produced natural gas annually for the price of USD 53 per 1,000 cubic meters. The declared purpose is social - the sale of cheap gas to poor users. In reality, up to half the gas is sold at the inflated prices of Russian gas (USD 485), for Ukraine has neither a centralized system for accounting for gas supplies nor a competitive gas market.

22 Sikora, "Budget 2014."

${ }^{23}$ In fact the prime cost of illegal gas is several times lower than the market price. However, after this gas is legalized as having been produced in a government well, its price increases by several factors. Thus, the owners of illegal gas wells make money twice - on the price machinations and on subsidies from the budget.

24 "Cabinet of ministers has approved a plan to deal with illegal coal mining," Union of Coal Industry Workers, 13 January 2014, available at http://www.prupu.org/news/ 18361/.

25 Anders Oslund, an expert in the economies of post-Soviet states, pointed out that the sum of ten billion USD, which ex-First Deputy Prime Minister Arbuzov was seeking from the EU, is the same amount which by the most modest of estimates is disappearing from the national budget as a result of their machinations. Anders Aslund, "Payback Time for the 'Yanukovych Family,"' RealTime Economic Issues Watch, 11 December 2013, available at http://blogs.piie.com/realtime/?p=4162. 
and 3) the presumption that Putin would agree to meet Yanukovych's financial needs, both state and personal (credit and access to gas deals).

The revolutionary events at Kyiv's Maidan square turned out to be a threat that neither Yanukovych nor Putin had taken into account. Accordingly, both leaders went to great lengths to suppress the protests. ${ }^{26}$ On the eve of the open aggression, Ukraine was on the verge of defaulting, with its state institutions (army, police, judicial system, security service, and most national executive bodies) completely disabled. ${ }^{27}$

By the time the crisis came to a head, the major sectors of the Ukrainian economy were involved in semi-legal, semi-criminal transnational business schemes. Instruments of budgetary and fiscal policy were used to illegally extract a significant portion of the national GDP from the economy.

As a result of the Kremlin's intentional policy, with members of the former Ukrainian regime and Russian security services acting as providers, Ukraine was transformed into an economically vulnerable and institutionally weak state. For international observers, the annexation of Crimea was the turning point in understanding the Ukraine crisis. However, the loss of Crimea was only the beginning of the invasion's open phase. Analysis of the situation from the standpoint of political and economic realities is the key to understanding the strategy and tactics of the intervention. Accordingly, the unconventional war against Ukraine had begun long before it was noticed. In an era of hybrid warfare the threats also become hybrid - indistinct, veiled, distorted, and so on. When the aggressor is constrained (for various reasons) from using traditional weapons, it may use substitutes. In the case of Ukraine, it is clear that the use of non-standard tactics of "directed disruption" of the enemy's governing authorities and economic system gives the aggressor a clear advantage without resorting to armed confrontation.

${ }^{26}$ Kapsamun, "Watershed Line." According to testimony from the SSU, at least three groups of high-ranking officials from the Russian Federation FSB were working within the Security Service of Ukraine from December 2013 through February 2014. During those months, all the modern weapons, personal files, archives-everything that a professional security service is based upon-were taken to Crimea. In recent years, Russian agents have had a constant presence in Ukrainian special security units, and during revolutionary activities have actively worked to develop and implement plans to suppress those activities (clearing of Maidan, kidnapping of activists, shooting people). Moreover, Putin's regime, presumably in concert with Yanukovych, was preparing for the annexation of Crimea and for events in Donbas. As early as March 2014, the SSU discovered separatist organizations in the territory of the Lugansk and Donetsk oblasts that were actually subversive groups. They had stores of weapons and money at their disposal. It was also established that the former commander of interior troops, ex-Minister of Internal Affairs Zakharchenko, and the former head of the SSU were involved in recruiting mercenaries and organizing shipments of arms into Ukrainian territory. pubs/ft/scr/2014/cr14106.pdf. 
In late July 2014, as work on this article was coming to a close, there appeared a fragile hope for a quick conclusion to the strange war in Donbass. However, the prospects for a more sustainable peace are difficult to achieve in the medium term. It stands to reason that social and economic problems on the one hand and dissatisfaction among oligarchic groups with the outcome of the conflict's hot phase on the other will provoke and tempt the outside aggressor to disrupt Ukraine from within again and again.

\section{Conclusions and Recommendations for Ukraine}

The RF's aggressive policy has resulted in a manifold increase in the risks of trans-regionalization of conflicts, the spread of hostilities to other countries (primarily Ukraine's neighbors), the destabilization of border territories, the intensification of separatist processes, and ultimately an escalation of security threats to Central Europe and the Baltic and Black Sea regions.

The Ukrainian precedent may be replicated as a special operation to destroy statehood, whereby disruption is achieved through the escalation of internal political and economic challenges (of countries, regions, and international blocs). One universal means of undermining statehood in an era of hybrid wars is to encourage corruption among holders of the highest offices and to rely on systemic corruption in institutionally weak states.

In the case of Ukraine, macro-financial vulnerability in conjunction with a strained economic structure proved to be the necessary and sufficient conditions for preparing and implementing hybrid aggression in a neighboring state. The circumstances accompanying the unleashing of the armed conflict in Eastern Ukraine provide sufficient evidence to confirm the thesis that the specific economic interests of the actors in the conflict are instrumental to an armed conflict's onset as well as to impede its cessation. ${ }^{28}$

As such, there emerge three prominent recommendations for Ukraine. Firstly, the country should completely restructure the security sector, restore the capacities of the security service, law enforcement agencies, and military. The risks associated with addressing this task are a shortage of personnel, treason, and a lack of experience and resources. Secondly, it is necessary to strengthen the administrative and financial capacity of the institutions of government authority and dismantle the corrupt vertical structure. Addressing this

28 Paul Collier, "Economic Causes of Civil Conflict and Their Implications for Policy," in Leashing the Dogs of War, ed. Chester A. Crocker et al. (Washington, D.C.: USIP Press, 2007), also available at http://users.ox.ac.uk/ econpco/research/pdfs/ EconomicCausesofCivilConflict-ImplicationsforPolicy.pdf. Cf. also Ivan Briscoe, "Nonconventional armed violence and non-state actors: challenges for mediation and humanitarian action," The Norwegian Peacebuilding Resource Centre (NOREF), Report, May 2013, available at http://www.peacebuilding.no (accessed 20 July 2014); Mark B. Taylor, "Conflict Financing: What's Wrong with War Economies?" The Norwegian Peacebuilding Resource Centre (NOREF), Report, May 2013, available at http://www.peacebuilding.no/ (accessed 23 July 2014). 
task involves pursuing a strict anti-corruption policy and carrying out institutional and structural reforms in the spheres of activity most involved in illegal schemes (e.g. budget, public procurement, banking, and energy). Finally, the financial base of the separatist movement must be destroyed and the shadow business in Donbass and in other regions that serve as the primary social cover for the "separatist" movement must be brought to a halt. The risks include the impossibility of fully closing the channels through which resources flow from the RF, the lack of control over seized territories and centers of criminal business, and the weakening or destruction of the social welfare systems for persons wishing to leave the conflict zone.

\section{About the author}

Iryna Klymenko, a graduate of the George C. Marshall European Center for Security Studies (EPASS 11-10), is currently working as chief advisor at the "New Ukraine" Institute of Strategic Studies in Kyiv. In 2010-2014 she was the head of the Department of Foreign Policy at the National Institute for Strategic Studies, office of the President of Ukraine. She is a Candidate of Economic Sciences (2001) specializing in cooperation with international organizations.

E-mail: iryna.klimenko@gmail.com. 


\section{Bibliography}

1 December 2013 Euromaidan riots. Wikipedia: The Free Encyclopedia, 2014, http://en.wikipedia.org/wiki/1_December_2013_Euromaidan_riots.

Address by Andrey Illarionov, Senior Fellow at the Center for Global Liberty and Prosperity(link is external). InVilnius meeting of the Economic and Security Committee of the NATO Parliamentary Assembly. Washington, D.C.: Cato Institute, 2014.

Aslund, Anders. Payback Time for the 'Yanukovych Family'. RealTime Economic Issues Watch, 2013, http://blogs. piie.com/realtime/?p=4162.

Briscoe, Ivan. Non-conventional armed violence and non-state actors: challenges for mediation and humanitarian action. The Norwegian Peacebuilding Resource Centre (NOREF), 2013, http://www.peacebuilding.no.

Cabinet of ministers has approved a plan to deal with illegal coal mining. Union of Coal Industry Workers, 2014, http://www.prupu.org/news/18361/.

Collier, Paul. "Economic Causes of Civil Conflict and Their Implications for Policy." In Leashing the Dogs of War. Washington, D.C.: USIP Press, 2007, http://users.ox.ac.uk/ econpco/research/pdfs/EconomicCausesofCivilConflictImplicationsforPolicy.pdf.

Information from the State Financial Monitoring Service, 2014, http://www.sdfm.gov.ua/news.php?news_id=2546\&lang=uk;

http://www.sdfm.gov.ua/news.php?news_id=2592\&lang=en.

Kapsamun, Ivan. "Regarding the Watershed Line (Interview with Valentin Nalivaychenko)." Den [The Day] (2014), http://www.day.kiev.ua/ru/article/ podrobnosti-intervyu/o-linii-vodorazdela.

Klymenko, Iryna. The Prospects for Relations between Ukraine and the Customs Union of the Republic of Belarus, the Republic of Kazakhstan and the Russian Federation. Kyiv: National Institute for Strategic Studies, 2011.

Klymenko, Iryna. Ukraine in Integration Processes in the Post-Soviet Space: Modeling Alternatives. Kyiv: National Institute of Strategic Studies, 2013.

Lyamets, Sergey. Vladimir Dubrovksy: the Top-Down Power Structure Must Be Destroyed. Ekonomichna Pravda [Economic Truth], 2014, http://www.epravda.com.ua/publications/2014/06/18/466239/.

Memorandum. Lessons from the Ukraine Crisis: New Approaches to Security Policy (global, regional, national). New Ukraine, Institute of Strategic Studies, 2014, http://newukraineinstitute.org/new/399. 
Minutes of a plenary session of the Supreme Rada of Ukraine (Parliament of Ukraine). Parliament of Ukraine, 2014, http://iportal.rada.gov.ua/meeting/ stenogr/show/5641.html.

Regarding the decline (partial loss) of Ukraine's defense capabilities (20002014), In Expert study. Kyiv: Center for Army, Conversion and Disarmament Research, Defense Express, 2014, http://issuu.com/ukrainian_defense_ review/docs/.

Regarding the Informational and Psychological Component of the Russian Federation's Aggression against Ukraine, In based on events of 1-2 March 2014. Kyiv: Institute of Strategic Studies, 2014, http://en.niss.gov.ua/public/File/ englishpublic/Russia_aggression.pdf

Sikora, Ivan. Open Society Foundation, 2014, http://osf.org.ua/policy-analysisparlament/view/88.

Taylor, Mark B.. Conflict Financing: What's Wrong with War Economies? The Norwegian Peacebuilding Resource Centre (NOREF), 2013, http://www.peacebuilding.no/.

The sum total of state companies' debt is 140 billion UAH - Yatsenyuk. RBCUkraine, 2014, at www.rbc.ua/rus/news/politics/obshchaya-summa-dolgovgosudarstvennyh-kompaniy-sostavlyaet-27032014104500/.

Ukraine. Request for a Stand-By Arrangement. In IMF Country Report. Washington: International Monetary Fund, 2014, http://www.imf.org/external/ pubs/ft/scr/2014/cr14106.pdf.

Yanukovych's assets: a public initiative to gather information about the illicit assets of ex-president Yanukovych and his associates., 2014. 